\title{
Production Systems and Breeding Practices of Arab and Oromo Goat Keepers in Benishangul Gumuz Region, Northwestern Ethiopia: Implications for the Development of Community-based Breeding Programs
}

\author{
S. Oumer ${ }^{1,2, *} \quad$ A. Kefyalew ${ }^{2} \quad$ A.Haile ${ }^{3}$ \\ 1.Department of Animal Science, Assosa University, P.O.Box 18, Assosa, Ethiopia \\ 2.Department of Animal Production and Technology, Bahir Dar University, P.O.Box 79, Bahir Dar, Ethiopia \\ 3.International Centre for Agricultural Research in the Dry Areas, C/O ILRI Addis Ababa, P.O.Box 5689, Addis \\ Ababa, Ethiopia
}

\begin{abstract}
To better understand and describe the production systems and breeding practices of Arab and Oromo goat keepers, we undertook a household survey in semi-arid and sub-humid parts of Benishangul Gumuz region, Northwestern Ethiopia. Multi-stage random and probability proportional to size sampling techniques were employed to select peasant associations and households, respectively.Data were collected from 249 goat keeping households (86 in semi-arid and 163 in sub-humid areas) through personal observations, focus group discussions and structured questionnaires, and analyzed using SPSS. Descriptive statistics and indices were used to present the data. In both areas, goats were kept mainly to generate cash income followed by meat production and saving with overall indices of $0.40,0.23$ and 0.17 , respectively. The average \pm SD of flock sizes per households were $12.5 \pm 4.0$ in Arab goat keepers and $9.9 \pm 3.8$ in Oromo. The mean numbers of does, doe kids, bucks, kids and castrates were significantly higher in Arab goat keepers as compared to Oromo. Body size, twining ability and coat color were the most preferred attributes of both goat keepers in selecting breeding does while breeding bucks were selected based on their body conformation, growth and coat color. Mating was predominantly uncontrolled mainly due to communal grazing lands. Castration of bucks was significantly $(\mathrm{p}<0.01)$ more frequent in Arab goat keepers than Oromo. The average age at first kidding, kidding interval, reproductive lifetime and number of kids born per lifetime of Arab does were $13.9 \pm 1.7$ months, $7.2 \pm 1.8$ months, $7.2 \pm 2.0$ years and $10.7 \pm 2.5$, respectively. The corresponding values for Oromo does were $14.9 \pm 2.4$ months, $7.8 \pm 1.1$ months, $7.9 \pm 1.9$ years and $9.7 \pm 1.6$. The difference between Arab and Oromo goat keepers in terms of production objectives, flock sizes, trait preferences and breeding practices should be carefully considered in the development of breed improvement programs in the study areas.
\end{abstract}

Keywords: Arab goat, Breeding practice, Oromo goat, Production system, Traits

DOI: $10.7176 /$ ALST/73-03

Publication date: April $30^{\text {th }} 2019$

\section{Introduction}

The goat population of Ethiopia is currently estimated to be 30,200,226 heads (CSA, 2017) classified in 11 phenotypically (Awgichew and Abegaz, 2008) and 7 genetically (Mekuriaw, 2016) distinct breeds. The majority of the goat population is found in large flocks in arid and semi-arid lowlands while goats in the highlands are widely distributed with very small flock sizes (Solomon et al., 2014). Estimates indicate that $99.97 \%$ of the goats in Ethiopia are indigenous breeds (CSA, 2017). Their peculiar features such as adaptation to adverse climatic conditions, resistance to a wide range of diseases and parasitic loads and ability to better utilize poor quality feeds make indigenous goat populations valuable genetic resources in many tropical countries (Kosgey et al., 2008). Under these prevailing and hostile environments, indigenous goats of Ethiopia provide their owners with tangible and intangible benefits such as generation of cash income, production of meat, milk and manure, insurance against emergency and contribution to the socio-cultural events (Legesseet al., 2014).

Despite large number and multiple functions of goats in Ethiopia, productivity per unit of animal is very low and hence, their contribution to the national economy is far below the potential (Legese and Fadiga, 2014). Cognizant of this fact, attempts have been made to improve the productivity of indigenous goats through crossing with imported exotic breeds such as Anglo-Nubian, Boer, Saanen and Toggenberg (Solomon et al., 2014). However, the crossbreeding programs did not deliver the anticipated advantages to smallholder farmers mainly due to incompatibility of the genotypes with the farmers' breeding objectives, lack of proper understanding of the production systems and absence of participation of stakeholders in the designing of breeding strategies (Ayalewet al., 2003). Therefore, designing and implementation of appropriate and feasible breed improvement programs, based on the adapted indigenous breeds, can have immense contribution to improve the livelihood of smallholder farmers (Haile et al., 2013). Description of production systems and breeding practices are initial steps to develop sustainable improvement and conservation program of farm animal 
genetic resources (IBC, 2004; FAO, 2010).

Benishangul Gumuz region, located in the Northwestern Ethiopia, is a home for about 411,503 heads of goats (CSA, 2014) and five goat ecotypes (Agew, Arab, Felata, Gumuz and Oromo) (Getinet et al., 2005). Among these ecotypes, Gumuz and Agew goat populations, their production systems and breeding practices are the most studied. For instance, FARM-Africa (1996), Getinet et al. (2005), Halima et al. (2012a) and Abegaz et al. (2013) undertook on-farm phenotypic characterizations and described the production systems and breeding practices of both goat ecotypes. Their genetic diversity was also quantified using different molecular techniques (Halima, 2012b; Abegaz, 2014; Mekuriaw, 2016). However, Arab, Felata and Oromo goat ecotypes, their production environments and breeding practices were neglected in goat research and development activities of the country. The limited available information about the three goat populations, so far, has been based on onfarm survey and recall interviews (Getinet et al., 2005). Analysis of the production systems and breeding practices, with full participation of the community, are prerequisites to develop sustainable improvement and conservation program at smallholder level (Kohler-Rollefson and Rathore, 2006; Kosgeyet al., 2006). Therefore, the objective of the current study was to describe the production systems and breeding practices of Arab and Oromo goat keepers within and between the selected areas in Benishangul Gumuz region, Northwestern Ethiopia.

\section{Materials and Methods}

\section{Description of the study areas}

The study was carried out from December 2017 to February 2018 in Homosha and Bambasi districts of Assosa zone, Benishangul Gumuz region. The region is located in Northwestern Ethiopia and is divided into three zones i.e. Assosa, Kamashi and Metekel (Negasa, 2017). Assosa zone was selected because it is the breeding tract of both Arab and Oromo goat populations (Getinet et al., 2005). The districts were selected purposively to address goat production systems and breeding practices in two different agro-ecologies, farming systems and goat populations. The presence of Assosa Agricultural Research Center and Assosa University within reasonable distance of the districts was also considered in selecting the districts. The good relationship created between the institutes and the communities helped in facilitating the current study and will have a paramount importance in future designing and implementation of breed improvement strategies.

Homosha district is located in semi-arid agro-ecological zone at a distance of 711 kilometer from Addis Ababa to the Northwestern part of the country. It is bordered by Assosa in the south, Kurmuk in the northwest and Menge in the east (Homosha BoARD, 2018). The district extends from $6^{0} 44^{\prime}$ to $6^{0} 84^{\prime}$ north latitude and from $37^{0} 92^{\prime}$ to $38^{\circ} 6^{\prime}$ east longitude (Abebe and Wolde, 2010) at an average latitude of 1,373 meters above sea level (elevationmap.net, 2018). The rainfall pattern is erratic and uneven with a mean annual range from 7001,200 mm, most being occurred between May and September with the highest in July or August. The temperature varies from 20 to $30^{\circ} \mathrm{C}$. The district covers an estimated area of $645.78 \mathrm{~km}^{2}$ comprising 14 rural and 1 urban peasant associations (PAs) (the lowest administrative units in Ethiopia). The production systems are mixed crop-livestock and agro-pastoral. The district is known for its limited crop production due to poor soil fertility and unreliable rainfall (Homosha BoARD, 2018). Traditional goat production and breeding is practiced in the area. Arab goat, named after the Berta/Arab ethnic group, predominates in this study area.This goat type was considered as a dual-purpose (used for meat and milk production) type (Getinet et al., 2005).

The second study area, Bambasi district, named after the highest point in Assosa zone (mount Bambasi), is locatedin sub-humid agro-ecology of Northwestern Ethiopia, 640 kilometer away from Addis Ababa. It is bordered by Oda Bildigilu in the North, Begi and Mao-komo in the south, Menesibu in the east and Assosa in the west. The district is positioned at $9^{\circ} 45^{\prime}$ Nlatitude and $34^{\circ} 44^{\prime} \mathrm{E}$ longitude with an elevation of 1,668 meters above sea level (Latitude.to, maps, geolocated articles, latitude longitude coordinate conversion, 2018). The mean annual rainfall ranges from $900-1,500 \mathrm{~mm}$ and the average temperature is $28^{\circ} \mathrm{C}$. Dabus river that can irrigate up to 51,000 haof land originates in this district (Merkorewos, 2008). The total area coverage of the district is 2,210.16 $\mathrm{km}^{2}$ encompassing 41 rural and 2 urban peasant associations. A mixed crop-livestock system is the dominant production system. Maize, sorghum, finger millet, teff, haricot bean, and sesame are among the crops produced in the area while goat, cattle, sheep, mule, donkey and poultry are the livestock species kept by the households (BambasiBoARD, 2018). Oromo goat is the predominant type of goat in this study area. This goat type was considered as meat type (Getinet et al., 2005).

\section{Sampling techniques and sample size}

In order to know the distribution of the targeted goat populations and select representative districts, group discussion was made with livestock experts working in Assosa zone and districts within the zone. Based on the outcome of the discussion, two districts (Homosha and Bambasi) were purposively selected for this study to address goat production systems and breeding practices in two different agro-ecological zones, farming systems and goat populations. After field visits and additional discussions with livestock experts and key informants in the respective districts, eight PAs (Gumu-Abush, Sherkole, Tumet and Tsore-almetema from Homosha district 
and Bambasi 02, Mutsa 01, Shebora and Womba-selama from Bambasi) were selected. Goat population size (based on the available data from the respective districts' agricultural offices), presence of communal grazing areas, relative significance of goats to the livelihood of the communities, access to market and road were the criteria used in selecting the PAs. In order to clarify the objectives and possible outcomes of the research, meetings were held with the communities at each selected peasant association.

The number of sampled households was determined following the recommended formula (Arsham, 2007): $\mathrm{N}=0.25 /(\mathrm{SE})^{2}$; Where: $\mathrm{N}=$ sample size and $\mathrm{SE}=$ standard error. To make the size of the sample selected from each peasant association proportional to the size of the corresponding peasant association, probability proportional to size (PPS) sampling technique was employed as: $\mathrm{W}=[\mathrm{A} / \mathrm{B}] \mathrm{x} \mathrm{N}$; where: $\mathrm{W}=$ number of households to be calculated from the selected PA; $\mathrm{A}=$ total number of households in the selected $\mathrm{PA} ; \mathrm{B}=$ total number of households in all eight selected PAs and $\mathrm{N}=$ the calculated sample size (Reference).

Accordingly, assuming SE of 3.17\% and 95\% confidence level, the calculated sample size (N) was 249. Based on the information obtained from the districts, the number of households in the selected peasant associations were 315 (Gumu-Abush), 357 (Sherkole), 301 (Tumet), 259 (Tsore-almetema), 854 (Mutsa 01), 601 (Bambasi 02), 470 (Shebora) and 420 (Womba-selama) (Bambasi BoARD, 2018; Homosha BoARD, 2018). Therefore, the calculated numbers of households, following the PPS sampling method, were 22 (Gumu-Abushu), 25 (Sherkole), 21 (Tumet), 18 (Tsore-almetema), 59 (Mutsa 01), 42 (Bambasi 02), 33 (Shebora) and 29 (Womba-selama).

Finally, households who own at least four adult goats with a minimum of one year experience in goat husbandry practice and willing to participate in a community-based breeding program were identified and their lists were prepared in each peasant association with the help of data collectors. Starting from the first household, respondents were selected from the prepared list using systematic random sampling technique until the calculated sample size of each peasant association was maintained. In general, a total of 86 respondents from Homosha and 163 respondents from Bambasi districts were selected for interview.

\section{Data collection}

Semi-structured questionnaires and formal interviews were used to gather information from the selected households. Data on socioeconomic characteristics, purpose of keeping goats, flock size and composition, trait preference and selection criteria, mating system and sources of breeding buck, castration and reproductive characteristics were collected by trained enumerators from the respective peasant associations with close supervision by the researcher. The questionnaire was tested before the actual survey to ensure that all questions were of sufficient clarity for the interviewees. To generate additional information and validate the data collected from the individual farmers, participatory focus group discussions with elders, village leaders, women goat owners, youngsters, veterinarians and goat traders were also made in the selected peasant associations.

\section{Data management and analysis}

Data collected from the districts were encoded and fed into MS-Excel (2010) for further analysis using Statistical Package for Social Sciences version 22 (SPSS, 2013). Preliminary data analysis like homogeneity test, normality test and screening of outliers were employed before conducting the main data analysis. Chi-square or t-test was employed when required to test the independence of categories or to assess the statistical significance. Indices were calculated for ranked variables in reference to its formula: Index $=$ Sum of $(3 \mathrm{X}$ number of households ranked first $+2 \mathrm{X}$ number of households ranked second $+1 \mathrm{X}$ number of households ranked third) given for an individual reason divided by the sum of $(3 \mathrm{X}$ number of households ranked first $+2 \mathrm{X}$ number of households ranked second $+1 \mathrm{X}$ number of households ranked third) for overall reasons.

\section{Results and Discussion}

General household characteristics

Out of the total of 249 interviewed households, the overall majority (90\%) of the respondents were males. The proportion of male respondents was significantly $(\mathrm{p}<0.01)$ higher in Oromo goat keepers $(93.9 \%)$ than Arab (82.6\%). The mean (SD) age of the respondents was 47.1 (13.0) and 45.1 (9.7) years in Arab and Oromo goat keepers, respectively. This indicates that people of middle age were more likely engaged in goat farming and its implication in accepting new approaches such as community-based breeding programs could be higher given that young people are generally more receptive to innovations and new technologies than old ones (Adesina et al. 2000). The overall average family size of goat keepers was $7.94 \pm 4.2$ and it was higher than the national average of 4.80 (CSA, 2010b). Arab goat keepers have significantly $(\mathrm{p}<0.05)$ higher family size $(8.8 \pm 3)$ than Oromo goat keepers $(7.5 \pm 4.4)$. The difference might be due to the observed prevalence of polygamous marriage in the Arabs.

While $38.6 \%$ of the Oromo goat keepers attended primary, secondary and adult education, a significantly $(\mathrm{p}<0.01)$ lower proportion $(22.1 \%)$ of respondents in Arab goat keepers were literate. Complete absence of 
record keeping and identification of goats as observed among the interviewed farmers might be the result of high illiteracy rate in the study areas. This necessitates awareness creation among goat keepers and provision of simple and easy-to-use recording system. Nevertheless, the better literacy rate in Oromo goat keepers would be a good opportunity to implement goat improvement program as it might be helpful in performance and pedigree recording (Kosgey and Okeyo, 2007).

The marital status of Arab and Oromo goat keepers varied significantly $(\mathrm{p}<0.05)$. In Arab goat keepers, $98.8 \%$ was married and $1.2 \%$ was divorced, whereas married and divorced goat keepers represented $89 \%$ and $1.6 \%$ of the Oromo goat keepers, respectively. The rest of the Oromo goat keepers were widowed $(6.1 \%)$ and single $(3.1 \%)$. The average privately owned land per household was $2.3 \pm 1.8$ and $1.9 \pm 1.6$ hectare in Arab and Oromo goat keepers, respectively. The private lands were used mainly for crop production and communal grazing areas were available for grazing. Generally, the socio-economic differences of the households should be properly considered in designing of goat improvement programs in both study areas.

\section{Purpose of keeping goats}

In the present study, the most frequently reported purposes for keeping goats in both study areas were generation of cash income followed by meat production and saving (using goats as "village bank") with overall index values of $0.40,0.23$ and 0.17 , in that order (Table 1). These results clearly show that goats were kept in the rural areas of Benishangul Gumuz region not only for generation of cash income but also to supplement the diets of households through their meat. While the indices for other purposes were relatively small, keeping goats as a sign of wealth status in Arab goat keepers (0.12) and for manure production in Oromo goat keepers $(0.10)$ was of some importance.

None of the interviewed households in this study raised goats for milk production. This is because consumption of goat milk was considered as a cultural taboo in both study areas. Similar findings on goat milk consumption were reported in different parts of Ethiopia like Jimma (Belete, 2009), Metema (Tesfaye, 2009), North Gondar (Alubel, 2015) and Horro Guduru (Ahmed et al., 2015). However, the current result contrasts with reports in Sekota (Muluken, 2006), Dire Dawa (Grum, 2010), west Amhara (Kefyalew et al., 2015), Afar (Feki et al., 2015) and many African countries (Dubeuf, 2007). Lack of awareness of its nutritional and medicinal values is probably the possible explanation for low preference and acceptance of goat milk in Ethiopia in general and the study areas in particular. Overall, given the different purposes and ranks that farmers have for keeping goats, the main breeding goal of Arab and Oromo goat keepers is defined as increasing meat production for marketing and home consumption.

Table 1: Ranks and indices of purposes for keeping goats

\begin{tabular}{|c|c|c|c|c|c|c|c|c|c|}
\hline \multirow[t]{3}{*}{ Purpose } & \multicolumn{4}{|c|}{ Arab goat keepers $(\mathrm{N}=86)$} & \multicolumn{4}{|c|}{ Oromo goat keepers $(\mathrm{N}=163)$} & \multirow{3}{*}{$\begin{array}{c}\text { Overall } \\
\text { Index }\end{array}$} \\
\hline & \multicolumn{3}{|c|}{ Rank } & \multirow[t]{2}{*}{ Index } & \multicolumn{3}{|c|}{ Rank } & \multirow[t]{2}{*}{ Index } & \\
\hline & $\mathbf{1}^{\text {st }}$ & $2^{\text {nd }}$ & $3^{\text {rd }}$ & & $1^{\text {st }}$ & $2^{\text {nd }}$ & $3^{\text {rd }}$ & & \\
\hline Income & 55 & 17 & 7 & 0.40 & 100 & 33 & 14 & 0.39 & 0.40 \\
\hline Meat & 9 & 27 & 17 & 0.19 & 24 & 79 & 30 & 0.27 & 0.23 \\
\hline Milk & 0 & 0 & 0 & 0.00 & 0 & 0 & 0 & 0.00 & 0.00 \\
\hline Saving & 12 & 15 & 22 & 0.17 & 18 & 24 & 53 & 0.16 & 0.16 \\
\hline Wealth status & 1 & 19 & 19 & 0.12 & 4 & 11 & 26 & 0.06 & 0.09 \\
\hline Manure & 5 & 6 & 18 & 0.09 & 16 & 10 & 30 & 0.10 & 0.10 \\
\hline Skin & 4 & 2 & 3 & 0.03 & 1 & 6 & 10 & 0.03 & 0.03 \\
\hline
\end{tabular}

Flock size and composition

The average flock size of a household was $12.5 \pm 4.0$ heads (ranging from 3 to 27goats) in Arab goat keepers and $9.9 \pm 3.8$ heads (ranging from 3 to 27 goats) in Oromo (Table 2). The current results are comparable with 10.8 goats per household in western lowland goats, but lower than 48.5 in Abergelle goats (Abegaz et al., 2013). On the other hand, Ahmed et al. (2015) reported a relatively small flock size (7.6) in western Ethiopia. The variations in flock sizes of goats might be due to the differences in production system and production environment, the role of livestock as major source of livelihood and availability of land and feed (Solomon et al., 2014).

The mean numbers of does (females above 1 year) and doe kids (females between 6-12 months) were significantly $(p<0.01)$ higher in Arab goat keepers than in Oromo. Similarly, the mean numbers of bucks (males above 1 year), kids (both males and females less than 6 months) and castrates were significantly $(p<0.05)$ higher in Arabs. Breeding does constituted the highest proportion (37.5\%) followed by kids (22.6\%), doe kids(20.3\%), buck kids (8.6\%), bucks (7.2\%) and castrates (3.9\%) in Arab goat flocks. A similar pattern was observed in Oromo goat flocks by which breeding does were dominant $(35.9 \%)$ followed by kids $(24.9 \%)$, doe kids $(20.6 \%)$, buck kids $(8.4 \%)$, bucks $(7.3 \%)$ and castrates $(3 \%)$. 
Larger proportion of breeding does obtained in the present study could imply the practice of retaining does for breeding purpose and the production of more number of kids. This in turn might be advantageous to implement village-based selection as it increases selection intensity and effectiveness of selective breeding. On the other hand, bucks and buck kids had lower proportion as compared to their female counter parts. This might be due to the removal of males for sale or home consumption. The ratio of breeding buck to breeding does was about 1:5 in Arab goats and the same in Oromo. The result is lower than the recommended ratio of 1:25 for tropical traditional production system (Wilson and Durkin, 1988). The higher ratio obtained in this study revealed that sufficient number of male goats were kept in the flock for breeding purpose. Castrated goats represented the lowest share of the flock per household in both goat keepers and the practice of goat castration might be helpful to avoid mating of unwanted bucks.

Table 2: Age class of goats in the flocks bystudy goat keepers

\begin{tabular}{|c|c|c|c|c|c|c|c|}
\hline \multirow[b]{2}{*}{ Age class } & \multicolumn{3}{|c|}{ Arab goat keepers $(\mathrm{N}=86)$} & \multicolumn{3}{|c|}{ Oromo goat keepers $(\mathrm{N}=163)$} & \multirow[b]{2}{*}{ P-value } \\
\hline & Mean \pm SD & Range & $\%$ & Mean \pm SD & Range & $\%$ & \\
\hline Flock size & $12.5 \pm 4.0$ & $7-28$ & 100 & $9.9 \pm 3.8$ & $3-27$ & 100 & \\
\hline Does & $4.7 \pm 1.6$ & $1-11$ & 37.5 & $3.6 \pm 1.6$ & $0-12$ & 35.9 & $* *$ \\
\hline Bucks & $0.9 \pm 0.7$ & $0-2$ & 7.2 & $0.7 \pm 0.7$ & $0-3$ & 7.3 & $*$ \\
\hline Doe kids & $2.5 \pm 1.5$ & $0-11$ & 20.3 & $2.0 \pm 1.3$ & $0-5$ & 20.6 & $* *$ \\
\hline Buck kids & $1.1 \pm 1.0$ & $0-3$ & 8.6 & $0.8 \pm 1.0$ & $0-4$ & 8.4 & NS \\
\hline Kids & $2.8 \pm 1.2$ & $0-6$ & 22.6 & $2.5 \pm 1.3$ & $0-8$ & 24.9 & $*$ \\
\hline Castrated & $0.5 \pm 0.8$ & $0-4$ & 3.9 & $0.3 \pm 0.6$ & $0-5$ & 3 & $*$ \\
\hline
\end{tabular}

$N=$ Number of households, $S D=$ Standard deviation, $N S=$ Non-significant, ${ }^{*} p<0.05,{ }^{*} p<0.01$

\section{Trait Preference and selection criteria}

Table 3 summarizes the relative importance of different traits as ranked by the goat keepers. Irrespective of keepers, results from the trait preference of households indicated that body size, twining ability, coat color and kid growth were the most preferred traits in selecting breeding does with overall index values of $0.34,0.22,0.17$ and 0.10 , respectively. Likewise, body conformation (wide chest, long body and up right standing) followed by fast growth, coat color and libido were found to be the most important selection criteria of breeding bucks with indices of $0.30,0.24,0.20$ and 0.08 , respectively. Traits such as kidding frequency, age at first maturity, kid/s survival and mothering ability in does and adaptability, ability to walk long distance, horns, age at first maturity, character and pedigree in bucks were also mentioned as selection criteria, but with lower ranking.

High preference of twining ability in the present study indicates the genetic potential of Arab and Oromo goats for multiple births and the farmers' general objective which is to increase flock size and overall flock productivity. Similarly, high emphasis on body size/conformation, fast growth and coat color in both sexes might be due to the observed market condition. Larger sized goats fetch premium market price and fast growing goats reached market weight sooner. Due to these conditions, goat keepers in the study areas tend to sale off good looking and fast-growing goats, particularly bucks that are potentially "best" breeding at early age to fetch better market price. This implies that bucks with unwanted traits are replicating which resulted in negative selection that may compromise the livelihoods of the producers. Awareness creation on Arab and Oromo goat keepers about negative selection is therefore highly recommended. Moreover, community level selection of bucks and using them effectively before they are sold off is suggested. 
Table 3:Ranks and Indices for trait preference of breeding does and bucks

\begin{tabular}{|c|c|c|c|c|c|c|c|c|c|}
\hline \multirow[t]{3}{*}{ Traits } & \multicolumn{4}{|c|}{ Arab goat keepers $(\mathrm{N}=86)$} & \multicolumn{4}{|c|}{ Oromo goat keepers $(\mathrm{N}=163)$} & \multirow{3}{*}{$\begin{array}{c}\text { Overall } \\
\text { Index }\end{array}$} \\
\hline & \multicolumn{3}{|c|}{ Rank } & \multirow[t]{2}{*}{ Index } & \multicolumn{3}{|c|}{ Rank } & \multirow[t]{2}{*}{ Index } & \\
\hline & $1^{\text {st }}$ & $2^{\text {nd }}$ & $3^{\text {rd }}$ & & $1^{\text {st }}$ & $2^{\text {nd }}$ & $3^{\text {rd }}$ & & \\
\hline \multicolumn{10}{|l|}{ Traits for does } \\
\hline Size & 42 & 21 & 11 & 0.35 & 71 & 42 & 21 & 0.33 & 0.34 \\
\hline Coat color & 8 & 20 & 24 & 0.17 & 9 & 53 & 36 & 0.17 & 0.17 \\
\hline Kid growth & 9 & 11 & 9 & 0.11 & 13 & 13 & 23 & 0.09 & 0.10 \\
\hline Kid survival & 3 & 9 & 6 & 0.06 & 3 & 4 & 8 & 0.03 & 0.05 \\
\hline kidding frequency & 0 & 2 & 5 & 0.02 & 0 & 1 & 13 & 0.02 & 0.02 \\
\hline Twining ability & 18 & 21 & 14 & 0.21 & 44 & 34 & 29 & 0.23 & 0.22 \\
\hline Mothering ability & 5 & 2 & 12 & 0.06 & 11 & 13 & 21 & 0.08 & 0.07 \\
\hline Milk yield & 0 & 0 & 0 & 0.00 & 0 & 0 & 0 & 0.00 & 0.00 \\
\hline Age at first maturity & 1 & 0 & 5 & 0.02 & 12 & 3 & 12 & 0.06 & 0.04 \\
\hline \multicolumn{10}{|l|}{ Traits for bucks } \\
\hline Conformation & 39 & 14 & 17 & 0.31 & 68 & 28 & 26 & 0.29 & 0.30 \\
\hline Coat color & 14 & 17 & 18 & 0.18 & 25 & 47 & 34 & 0.21 & 0.20 \\
\hline Horns & 0 & 3 & 4 & 0.02 & 0 & 5 & 1 & 0.01 & 0.01 \\
\hline Character & 1 & 4 & 12 & 0.04 & 4 & 13 & 21 & 0.06 & 0.05 \\
\hline Growth & 20 & 24 & 14 & 0.24 & 43 & 43 & 29 & 0.25 & 0.24 \\
\hline Libido & 5 & 15 & 11 & 0.11 & 1 & 9 & 14 & 0.04 & 0.08 \\
\hline Ability to walk long distance & 0 & 1 & 1 & 0.01 & 0 & 0 & 1 & 0.001 & 0.01 \\
\hline Age at first maturity & 3 & 2 & 3 & 0.03 & 14 & 1 & 15 & 0.06 & 0.05 \\
\hline Pedigree & 3 & 5 & 3 & 0.04 & 8 & 16 & 11 & 0.07 & 0.06 \\
\hline Adaptability & 1 & 1 & 3 & 0.02 & 0 & 1 & 11 & 0.01 & 0.01 \\
\hline
\end{tabular}

\section{Mating system and sources of breeding bucks}

The majority of the respondents in Arab (69.8\%) and Oromo (92\%) goat keepers practiced uncontrolled mating (Table 4). Predominance of uncontrolled mating within households' flocks was also reported in Ethiopia (Tekleyohannes, 2012; Abegaz et al., 2013; Hulunim; 2014; Netsanet et al., 2014). In contrast to these, controlled mating through selection, culling, castration and physical restriction was practiced in Afar goats (Feki et al., 2015). The main reasons for the absence of controlled mating in the present study were communal grazing areas (81.4\% in Arab and $92.6 \%$ in Oromo) and lack of farmers' awareness about the deleterious effects of inbreeding (18.6\% in Arab and 7.4\% in Oromo). An advantage of natural uncontrolled mating is that it allows for all year round parturition (Kosgey, 2004).

Most of the Arab (95.3\%) and Oromo (80.4\%) goat keepers practiced mixing of their flocks during grazing, on average with 5 other flocks in Arab and 3 other flocks in Oromo. This would minimize the problem of inbreeding by increasing the probability of mating of unrelated animals (Jaitner et al., 2001). Nearly two-third $(65.1 \%)$ of the respondents in Arab goat keepers and the majority (81\%) in Oromo used breeding bucks born within the flock whereas $27.9 \%$ of Arab and $10.4 \%$ of Oromo used neighbors'/communal bucks and the rest purchased breeding bucks from the nearby market. The main reasons of keeping bucks were mating, fattening and both. The average service year of a buck in the flock was $3.8 \pm 1.54$ years in Arab and $4.1 \pm 1.31$ years in Oromo; after which it will be usually castrated or disposed through sale or slaughter. Apparently, the average age at which the breeding buck is changed, revealed in Arab community, could be relatively better in the prevention of inbreeding. Generally, uncontrolled mating together with small flock sizes, utilization of breeding bucks born within the flock and poor record keeping on the pedigree would result in severe inbreeding and decreased genetic diversity (Saico and Abul, 2007). Equally important to note is that bucks were kept up to 3-5 years in the study areas. The implication of these results is that community-based breeding scheme would be appropriate for both Arab and Oromo goat keepers. 
Table 4: Mating system and sources of breeding buck

\begin{tabular}{|c|c|c|c|c|}
\hline \multirow[t]{2}{*}{ Descriptor } & \multicolumn{2}{|c|}{ Arab goat keepersOromo goat keepers } & \multirow[t]{2}{*}{$\mathbf{X}^{2}$} & \multirow[t]{2}{*}{ P-value } \\
\hline & $(\mathrm{N}=86)(\%)$ & $(\mathrm{N}=163)(\%)$ & & \\
\hline Mating system & & & 21.11 & $* *$ \\
\hline Controlled & $26(30.2)$ & $13(8)$ & & \\
\hline Uncontrolled & $60(69.8)$ & $150(92)$ & & \\
\hline Reasons for uncontrolled mating & & & 7.13 & $* *$ \\
\hline Communal grazing land & $70(81.4)$ & $151(92.6)$ & & \\
\hline Lack of awareness & $16(18.6)$ & $12(7.4)$ & & \\
\hline Mixing of individual flocks & & & 10.2 & $* *$ \\
\hline Yes & $82(95.3)$ & $131(80.4)$ & & \\
\hline No & $4(4.7)$ & $32(19.6)$ & & \\
\hline Source of breeding buck & & & 12.5 & $*$ \\
\hline Own flock & $56(65.1)$ & $132(81)$ & & \\
\hline Neighbor/communal & $24(27.9)$ & $17(10.4)$ & & \\
\hline Purchased from market & $6(7)$ & $14(8.6)$ & & \\
\hline Purpose of keeping breeding bucks & & & 7.14 & $* *$ \\
\hline Mating & $58(67.4)$ & $134(82.2)$ & & \\
\hline Fattening & $16(18.6)$ & $15(9.2)$ & & \\
\hline Mating and fattening & $12(14)$ & $14(8.6)$ & & \\
\hline Service year of a buck (Mean \pm SD) & $3.8 \pm 1.54$ & $4.1 \pm 1.31$ & & NS \\
\hline Number of households mixing their flocks $($ Mean \pm SD) & $5.6 \pm 2.9$ & $4.1 \pm 2.5$ & & $* *$ \\
\hline
\end{tabular}

\section{Castration}

Castration of bucks was a common phenomenon in both study areas, but it was significantly $(\mathrm{p}<0.01)$ more frequent in Arab goat keepers (97.7\%) than Oromo (60.1\%) (Table 5). The low rate of castration in Oromo goat keepers might be due to high demand of intact male goats in the area. Irrespective of keepers, fattening was found to be the most common reason of castration followed by control mating and better temperament. The frequency of castration methods differed significantly $(\mathrm{p}<0.05)$ between the keepers in that $63.8 \%$ of Oromo and $54.7 \%$ of Arab goat keepers used traditional castration method, by crushing the vas deferens using smooth and round river stone locally known as 'alello' and banded the testes until they wither due to lack of blood flow. The rest of keepers took their male goats to a nearby veterinary clinic to use burdizzo.

The mean age of castration in Arab goat keepers $(1.9 \pm 0.6$ years $)$ was significantly $(\mathrm{P}<0.05)$ lower than that of Oromo goats (2.2 \pm 1.1 years). These results are close to the findings of Hulunim (2014) and Abegaz et al. (2013) who documented $2.2 \pm 0.11$ and $2.10 \pm 0.68$ years for Borena and Western lowland goats, respectively. However, the current findings contrast with what has been recommended by Alemu (2009). The same author suggested castration of male kids as soon as the testicles descend into the scrotum, from a few days of age to three weeks. In general, the practice of castration in both study areas might be advantageous to design goat genetic improvement program through control of inbreeding and unwanted mating. However, castration of bucks before sexual maturity is recommended to avoid unwanted mating.

Table 5:Summary of castration

\begin{tabular}{|c|c|c|c|c|}
\hline Descriptor & $\begin{array}{c}\text { Arab goat keepers } \\
\mathrm{N}=86(\%)\end{array}$ & $\begin{array}{c}\text { Oromo goat keepers } \\
\mathrm{N}=\mathbf{1 6 3}(\%) \\
\end{array}$ & $\mathbf{X}^{2}$ & P-value \\
\hline Practice of castration & & & 40.36 & $* *$ \\
\hline Yes & $84(97.7)$ & $98(60.1)$ & & \\
\hline No & $2(2.3)$ & $65(39.9)$ & & \\
\hline Reason for Castration & & & 1.82 & NS \\
\hline Fattening & $72(83.7)$ & $139(85.3)$ & & \\
\hline Control mating & $10(11.6)$ & $12(7.4)$ & & \\
\hline Better temperament & $4(4.7)$ & $12(7.4)$ & & \\
\hline Castration methods & & & 1.98 & $*$ \\
\hline Traditional & $47(54.7)$ & $104(63.8)$ & & $*$ \\
\hline Modern & $39(45.3)$ & $59(36.2)$ & & \\
\hline Age of castration (Mean \pm SD) & $1.9 \pm 0.6$ & $2.2 \pm 1.1$ & & $*$ \\
\hline
\end{tabular}




\section{Reproductive performance}

The results obtained for reproductive performance of Arab and Oromo goats are presented in Table 6. There was significant $(\mathrm{P}<0.01)$ differences between the two goat populations, all reproductive performance traits being higher in Oromo goats than Arab goats. The average age at sexual maturity of Arab and Oromo male goats were found to be $7.0 \pm 1.0$ and $7.6 \pm 0.9$ months, respectively, in the meantime female goats were mated at an average age of $7.9 \pm 0.9$ and $8.3 \pm 0.7$ months, in that order. The average age at first kidding of Arab and Oromo goats were estimated to be $13.9 \pm 1.7$ and $14.9 \pm 2.4$ months, respectively. The present findings are within the range of 7-15 months of age at sexual maturity in both sexes and 12-20 months of age at first kidding for indigenous goats (Solomon et al., 2014). Similarly, the kidding interval obtained in the current study, $7.2 \pm 1.8$ months in Arab goats and $7.8 \pm 1.1$ months in Oromo goats, falls within the range of 180-300 days reported for tropical goat breeds (Banerjee et al., 2000).

A breeding doe can serve in the flock for an average of $7.2 \pm 2.0$ years in Arab and $7.9 \pm 1.9$ years in Oromo. For the corresponding areas, $10.7 \pm 2.5$ and $9.7 \pm 1.6$ mean numbers of kids were born per lifetime of does. The inverse relation of average reproductive lifetime of a doe and number of kids born per lifetime of a doe indicated that Arab goats have better reproductive performance than Oromo goats. This could be attributed to their genetic superiority or the environment. With regard to the environment, Arab goats predominate in semiarid zones whereas Oromo goats are found in sub-humid zones of Benishangul Gumuz region (Getinet et al., 2005). As elucidated by Solomon et al. (2014), the highest values for most reproductive traits, except kidding interval and average number of kids born, in the Ethiopian indigenous goat breeds were observed in goats from arid and semi-arid areas. Regarding the genetic superiority, molecular analysis of the two goat populations is recommended. In general, the reproductive performance of both Arab and Oromo goats is fairly good and in the short-term, this parameter may not be a priority for intervention and efforts at genetic improvement of goats in the study areas should be directed towards production traits.

Table 6: Average reproductive performance of goats as estimated by respondents

\begin{tabular}{|c|c|c|c|c|c|}
\hline \multirow[t]{2}{*}{ Parameters } & \multicolumn{2}{|c|}{$\begin{array}{l}\text { Arab goat keepers } \\
(\mathrm{N}=86)\end{array}$} & \multicolumn{2}{|c|}{$\begin{array}{c}\text { Oromo goat } \\
\text { keepers }(\mathrm{N}=163)\end{array}$} & \multirow[t]{2}{*}{ P-value } \\
\hline & Mean \pm SD & Range & Mean \pm SD & Range & \\
\hline Age at $1^{\text {st }}$ sexual maturity of male goats (months) & $7.0 \pm 1.0$ & $6-12$ & $7.6 \pm 0.9$ & $6-9$ & $* *$ \\
\hline Age at $1^{\text {st }}$ sexual maturity of female goats (months) & $7.9 \pm 0.9$ & $6-12$ & $8.3 \pm 0.7$ & $7-10$ & ** \\
\hline Age at $1^{\text {st }}$ kidding (months) & $13.9 \pm 1.7$ & $12-18$ & $14.9 \pm 2.4$ & $11-24$ & ** \\
\hline Kidding interval (months) & $7.2 \pm 1.8$ & $5-12$ & $7.8 \pm 1.1$ & $6-12$ & $* *$ \\
\hline Reproductive life time of does (years) & $7.2 \pm 2.0$ & $4-15$ & $7.9 \pm 1.9$ & $4-15$ & ** \\
\hline Number of kids born/life time/doe (number) & $10.7 \pm 2.5$ & $5-20$ & $9.7 \pm 1.6$ & $6-16$ & $* *$ \\
\hline
\end{tabular}

$N=$ Number of respondents, $S D=$ standard deviation, $* * p<0.01$

\section{Conclusions and recommendations}

The present study provided insights into the production systems and breeding practices of Arab and Oromo goat keepers in Benishangul Gumuz region, Northwestern Ethiopia. Goats were kept in both study areas for multiple purposes and keepers have an established practice of selecting breeding does and bucks. Increasing meat production (improving conformation and growth) for marketing and home consumption, twining ability and coat color were found to be the most preferred traits in defining breeding goals. Low level of literacy especially in the Arab goat keepers, negative selection, small flock size, poor recording, utilization of breeding bucks born within the flock are the characteristics of the study areas. Therefore, larger effort should be put on awareness creation on goat keepers of the study areas about inbreeding and negative selection. Strengthening the existed practice of mixing different goat flocks within the village based on communal grazing land is also suggested in order to make selection within village rather than within each flock of a household. Simplified and easy-to-use recording methods should be introduced to make selection based on recorded data. Overall, introduction of communitybased breeding programs, considering the difference between Arab and Oromo goat keepers' production systems and breeding practices, are highly recommended to improve the livelihood of the goat keepers.

\section{Declarations}

Ethics approval and consent to participate

The review paper meets all applicable standards with regard to ethics and integrity. As a researcher and educator in animal breeding and genetics and along with the co-author, the paper has been submitted with full responsibility, following due ethical procedure, and there is no duplicate publication, fraud or plagiarism.

\section{Consent for publication}

Not applicable 


\section{Availability of data and material}

Data sharing is not applicable to this article as no datasets were generated or analyzed during the current study.

\section{Funding}

Not applicable

\section{Authors' contributions}

Mr. Oumer Sheriff drafted and organized the manuscript while Drs. Kefyalew Alemayehu and Aynalem Haile participated in coordination and helped to draft the manuscript. All the authors read and approved the final manuscript.

\section{Acknowledgement}

The corresponding author gratefully acknowledges the Federal Ministry of Education, Ethiopia, Assosa and Bahir Dar Universities for the PhD fellowship award.

\section{Competing Interests}

The authors declare that they have no competing interests

\section{References}

Abebe R. and Wolde A. (2010). Preliminary survey on equine trypanosomosis and its vectors in Asosa and Homosha districts in Benishangul Gumuz Regional State, northwest Ethiopia. Livestock Research for Rural Development.Volume 22, Article \# 18. Retrieved December 2, 2018, from http://www.lrrd.org/lrrd22/1/abeb22018.htm

Abegaz S.G. (2014). Design of community based breeding programs for two indigenous goat breeds of Ethiopia. Doctoral Thesis: University of natural resources and applied life sciences, department of sustainable agricultural systems division of livestock sciences. Vienna, Austria.

Abegaz S.G., Sölkner J., Gizaw G., Dessie T., Haile A. and Wurzinger M. (2013). Description of production systems and morphological characteristics of Abergelle and Western lowland goat breeds in Ethiopia: implication for community-based breeding programmes. Animal Genetic Resources. 53, 69-78. doi:10.1017/S2078633613000088.

Adesina AA, Mbila D, Nkamleu BG, Endamana D. (2000).Econometric analysis of the determinants of adoption of alley farming by farmers in the forest zone of southwest Cameroon. Agric Ecosyst Environ. 80:255-256. doi: 10.1016/S0167-8809(00)00152-3.

Ahmed S., Kefelegne K. and Kefena E. (2015). Breeding Objective, Selection Criteria and Breeding Practice of Indigenous Goats in Western Ethiopia: Implications for Sustainable Genetic Improvement. Greener Journal of Agricultural Sciences. Vol. 5 (5), pp. 167-176. DOI http://doi.org/10.15580/GJAS.2015.5.072715105.

Alemu Y. (2009). Castration of sheep and goats. Technical Bulletin No.18.Ethiopia Sheep and Goat productivity Improvement Program. R.C. Merkel (ed.). 12Pp.

Alubel A (2015).On-Farm Phenotypic Characterization and Performance Evaluation of Abergelle and Central Highland Goat Breeds as an Input for Designing Community-Based Breeding Program. Msc Thesis presented to Haramaya University. Dire Dawa, Ethiopia.

Arsham, H. (2007): Business Statistics, Decision Science and Systematic Simulation. Merrick Schol of Business. Charles at Mount Royal, Baltimore, Maryland, 21201. University of Baltimore, USA.

Awgichew, K. and S. Abegaz (2008).Breeds of sheep and goats. In: Alemu Yami and R.C. MERKEL (eds.). Sheep and goat Production Hand Book for Ethiopia. Ethiopian Sheep and Goats Productivity Improvement Program (ESGPIP), Addis Ababa, Ethiopia, pp: 59-72.

Ayalew W, Rischkowsky B, King J M and Bruns E (2003). Crossbreds did not create more net benefits than indigenous goats in Ethiopian smallholdings. Agricultural System, 76:1137-1156.

Bambasi BoARD (2018). Bambasi Bureau of Agriculture and Rural Development.Physical and socio-economic profile of Bambasi district. Unpublished report. Bambasi, Ethiopia.

Banerjee, A.K, G. Animut and E. Ermias (2000).Selection and breeding strategies for increased productivity of goats in Ethiopia. In: R.C Merkel, G.Abebe and A.L. Goetsch (eds). The opportunities and challenges of enhancing goat production in East Africa. Proceedings of a conference held at Debub University, Awassa, Ethiopia from November 10 to 12, 2000. E (Kika) de la Garza Institute for Goat research, Langston University, Langston, OK pp.70-79.

Belete S (2009). Production and marketing systems of small ruminants in Goma district of Jimma zone, western Ethiopia. M Sc Thesis. School of Graduate Studies, Hawasa University of Agriculture.

CSA (2010b). Federal Democratic Republic of Ethiopia Central Statistical Agency, Agricultural sample survey, Report on livestock and livestock holding characteristics. Statistical Bulletin No.468, Vol.2, Addis Ababa 
Ethiopia.

CSA (2014). Federal Democratic Republic of Ethiopia Central Statistical Agency. Key findings of the 2013/2014 (2006 E.C.) agricultural sample survey. Country Summary. Addis Ababa, Ethiopia, October, 2014.

CSA (2017). Federal Democratic Republic of Ethiopia Central Statistical Agency, Agricultural sample survey, Report on livestock and livestock holding characteristics. Statistical Bulletin No.585, Vol.2, Addis Ababa Ethiopia, April, 2017.

Dubeuf J.P, (2007). Characteristics and diversity of the dairy goat production systems and industry around the world.Structural, market and organizational conditions for their development.Paper presented at SINCORTE, Joao Pessoa, Paraiba, Brazil, November 2007 (published with the approval of the Coordination of SINCORTE)

Elevationmap.net. (2018). Homosha Town, Homosha, Asosa, Ethiopia on the Elevation Map. Topographic Map of Homosha Town, Homosha, Asosa, Ethiopia. [online] Available at: https://elevationmap.net/homoshatown-homosha-asosa-et-1011136468 [Accessed 2 Dec. 2018].

FAO (2010). Breeding strategies for sustainable management of animal genetic resources. FAO Animal Production and Health Guidelines.No. 3. Rome, Italy, FAO (available at: http://www.fao.org/docrep/012/i1103e/i1103e.pdf).

FARM Africa (1996). Goat types of Ethiopia and Eritrea. Physical description and management systems.Published jointly by FARM-Africa, London, UK and ILRI (International Livestock Research Institute), Nairobi, Kenya.

Feki M., Berhanu B. and Aynalem H. (2015). Participatory definition of trait preference and pastorals' indigenous knowledge on goat breeding strategy around Aysaita district, Ethiopia. Livestock Research for Rural Development 27 (8) 2015.

Getnet A., Hegde, B.P., Bekele T., Enyew N. and Workneh A. 2005. Phenotypic characterization of goat types in northwestern Ethiopia. Ethiopian Journal of Animal Production 5:13-32.

Grum G (2010). Community based participatory characterization of the short-eared Somali goat population around Dire Dawa. MSc thesis.

Haile A., Maria W., Joaquín M., Tadele M., Gemeda D., Okeyo M., Johann S. and Barbara R. (2011). Guidelines for Setting up Community-based Sheep Breeding Programs in Ethiopia. ICARDA - tools and guidelines No.1. Aleppo, Syria, ICARDA.

Halima H, Michael B, B Rischkowsky and Tibbo M (2012a). Phenotypic characterization of Ethiopian indigenous goat populations. African Journal of Biotechnology 11(73):13838-13846.

Halima, H Lababidi, S Rischkowsky B Baum M and Tibbo M (2012b).Molecular characterization of Ethiopian indigenous goat populations. Tropical Animal Health Production 44(6):1239-1246.

Homosha BoARD (2018). Homosha Bureau of Agriculture and Rural Development.Physical and socioeconomic profile of Homosha district. Unpublished report. Bambasi, Ethiopia.

Hulunim G (2014). On-Farm Phenotypic Characterization and Performance Evaluation of Bati, Borena and Short-Eared Somali Goat Populations of Ethiopia. MSc thesis, Submitted to the School of Graduate Studies of Haramaya University, Ethiopia.

IBC (2004). Institute of Biodiversity Conservation. Domestic animal genetic resources of Ethiopia. Web-site (http://www.ibc-et.org/ibc/dpt/animal/domestic_animals.html)

Jaitner J, Sowe J, Secka-Njie E and Dempfle L (2001).Ownership pattern and management practices of small ruminants in The Gambia-implications for a breeding programme. Small Ruminant Research, 40:101-108.

Kefyalew A., Damitie K., Alemash M. and Sileshi A. (2015).Selection of Indigenous Goat Types for Designing Product Specific Breeding Strategy in Selected Districts of West Amhara, Ethiopia. World Applied Sciences Journal. Vol: 33 (8): 1279-1285, 2015: ISSN 1818-4952: DOI: 10.5829/idosi.wasj.2015.33.08.15595.

Kohler-Rollefson, I. and H. S. Rathore (2006). Documentation of animal genetic resource; the life method.LEISA (Center for Information on Low External Input and Sustainable Agriculture) magazine.Vol. 22. No. 1, March 2006. Amerstfoort, The Netherlands.

Kosgey I.S (2004). Breeding objectives and breeding strategies for small ruminants in the Tropics. Ph.D. Thesis, Wageningen University, the Netherlands. (ISBW: 90-5808-990-8) Germany.271p.

Kosgey I.S, Baker R.L, Udo H.M.J and van Arendonk J.A.M (2006). Successes and failures of small ruminant breeding programs in the tropics: a review. Small Ruminant Research, 61: 13-28.

Kosgey, I.S. and Okeyo, AM. (2007). Genetic improvement of small ruminants in low-input, smallholder production systems: technical and infrastructural issues. Small Ruminant Research, 70: 76-88.

Kosgey, I.S., Rowlands, G.J., van Arendonk, J.A.M. and Baker, R.L. (2008).Small ruminant production in smallholder and pastoral/extensive farming systems in Kenya. Small Ruminant Research, 77: 11-24.

Latitude.to, maps, geolocated articles, latitude longitude coordinate conversion. (2018). GPS coordinates of 
Bambasi, Ethiopia. Latitude: 9.7500 Longitude: 34.7333. [online] Available at: https://latitude.to/articlesby-country/et/ethiopia/329555/bambasi [Accessed 2 Dec. 2018].

Legese G and Fadiga M (2014). Small ruminant value chain development in Ethiopia: Situation analysis and trends. ICARDA/ILRI Project Report. Nairobi, Kenya: International Center for Agricultural Research in the Dry Areas/International Livestock Research Institute.

Legese, G., Haile, A., Duncan, A.J., Dessie, T., Gizaw, S. and Rischkowsky, B. (2014). Sheep and goat value chains in Ethiopia: A synthesis of opportunities and constraints. ICARDA/ILRI Project Report. Nairobi, Kenya: International Center for Agricultural Research in the Dry Areas/International Livestock Research Institute.

Mekuriaw G. (2016). Molecular Characterization of Ethiopian Indigenous Goat Populations: Genetic Diversity and Structure, Demographic Dynamics and Assessment of the Kisspeptin Gene Polymorphism. A PhD dissertation submitted to the department of Microbial, Cellular and Molecular Biology, Addis Ababa University, Addis Ababa, Ethiopia.

Merkorewos H. (2008). Assessment of Local Economic Development Potential and Proposal of Interventions for Bambasi and BullenWeredas. Study on Emerging Regions Development Program, UNDP/UNCDF and Ministry of Federal Affairs.

Muluken Z. (2006).Goat husbandry practices and productive performances in Sekota woreda of Amhara Region. An M.Sc. Thesis Presented to the School of Graduate Studies of Haramaya University, Haramaya, Ethiopia. 71p

Negasa D. (2017). The role of rural land registration in enhancing governance and tenure security of communal holding in Benishangul Gumuz regional state of Ethiopia: Can communal grazing land be saved from threats of encroachment by the non-holders?

Netsanet Z., Tadelle D. and Kefelegn K. (2016). Indigenous breeding practices and selection criteria of goat owners in Konso and Meta-Robi districts, Ethiopia: implications for designing community-based breeding strategy. Livestock Research for Rural Development 28 (7) 2016.

Saico, S., S. Abul, (2007). Socio-economic constraints on goat farming in the lowland of Swaziland.J. of Sustainable Devel.in Afr. 9: 37-49

Solomon, A.K., Mwai, O., Grum, G., Haile, A., Rischkowsky, B.A., Solomon, G. and Dessie, T. (2014). Review of goat research and development projects in Ethiopia. ILRI Project Report. Nairobi, Kenya: International Livestock Research Institute.

SPSS for windows (2013). Statistical Package for Social Science (SPSS).Release 22.0. The Apasche software foundation.

Tekleyohannes B, Jamroen T, Sayan T, Girma A, Asrat T and Somkiert P (2012). Purposes of keeping goats, breed preferences and selection criteria in pastoral and agro-pastoral districts of South Omo Zone. Livestock Research for Rural Development 24 (12) 2012.

Tesfaye T (2009). Characterization of Goat Production Systems and On-Farm Evaluation of the Growth Performance of Grazing Goats Supplemented With Different Protein Sources in Metema ,Amhara Region, Ethiopia. MSc Thesis, Submitted to the School of Graduate Studies of Haramaya University, Ethiopia. 108P.

Wilson R.T and Durkin J.W (1988). Small ruminant production in central Mali: reproductive Performance in traditionally managed goats and sheep. Livestock Production Sciences, 19:523-529. 